mgr inż. Damian Świderski ${ }^{1}$

dr inż. Florian G. Piechurski ${ }^{1}$

\title{
OCENA SPOSOBÓW OBNIŻENIA STRATY WODY NA PRZYKŁADZIE PWIK W A
}

\author{
https://doi.org/10.18778/8220-655-5.08
}

\begin{abstract}
Streszczenie: Przedstawione zostały sytuacje związanej ze stratami wody w PWiK w A. Analizowano różnorodne czynniki wpływające na objętość traconej wody oraz metody zmniejszania strat w analizowanym przedsiębiorstwie, takie jak zmiana struktury wiekowej, materiałowej oraz długość sieci wodociągowej i przyłączy w ciągu 7. lat. Przeanalizowano liczby awarii w sieci wodociągowej i przyłączach. Poziom strat wody zmniejszył się z 43. do $26,6 \%$, a celem przedsiębiorstwa jest osiągnięcie poziomu $8-12 \%$.
\end{abstract}

Słowa kluczowe: sieć wodociągowa, długość, materiały, straty, ocena strat wody, metody obniżania strat.

\section{Wprowadzenie}

W artykule przedstawiono sytuacje związane ze stratami wody w przykładowym PWiK w A. Analizie poddano różne czynniki wpływające na wielkość strat wody, jak również metody zmniejszania ich. Przeanalizowano także liczby awarii w sieci wodociągowej i przyłączach.

Problem strat wody występuje w każdym przedsiębiorstwie wodociągowym na świecie. Obliczane są one jako różnica objętości wody wtłoczonej do sieci i objętości wody sprzedanej użytkownikom oraz zużytej do potrzeb zakładu wodociągowego - są znaczne (Zygmanowski 1957). W ostatnich dwóch dekadach XX w. nieprawidłowo gospodarowano wodą i ją marnotrawiono, nie zastanawiano się, jak wielki udział zużywanej wody stanowią straty.

Od ok. 30. lat ogólne zużycie wody systematycznie spada, liczba odbiorców przyłączanych do systemów wodociągowych z roku na rok wzrasta, objętość sprzedawanej zafakturowanej wody spada przy pogłębianiu wielkości strat wody. Przedstawiona sytuacja zmusiła przedsiębiorstwa do walki z zaistniałym problemem oraz obniżania strat wody, zmniejszenia różnicy między zakupioną, wyprodukowaną wodą a sprzedaną (Mutikanga i in. 2013).

Poznanie przyczyn wycieków wody, ich wysokości oraz ciągłe działanie na rzecz ich ograniczenia jest jednym z głównych celów zakładów wodociągowych. Straty wody są podstawą oceny poprawności działania sieci i dlatego właściwe określenie ich wartości warunkuje prawidłową eksploatację systemu wodociągowego. W każdym, nawet bardzo poprawnie działającym systemie dystrybucji, pewna objętość wody wtłoczonej jest tracona i zakłady nie uzyskują przychodów z jej sprzedaży. Poważnym problemem są jednak straty wody stanowiące wysoki procent wody wtłaczanej do sieci. Dlatego też bardzo ważne jest szybkie lokalizowanie i usuwanie wycieków w celu ograniczenia ich do minimalnego poziomu charakterystycznego dla danego systemu dystrybucji wody. Jest to konieczne w celu oszczędzania zasobów wody oraz pozwala na zmniejszenie kosztów jej dostawy (Ferrari i Sawic 2015, EEA 2012, Clarke i in. 2012, Piechurski i Mierzwa 2020).

\footnotetext{
${ }^{1}$ Politechnika Śląska, Wydział Inżynierii Środowiska i Energetyki, Katedra Inżynierii Wody i Ścieków, ul. Konarskiego 18, 44-100 Gliwice, florian.piechurski@ polsl.pl, ORCID 0000-0001-8065-962X
} 


\section{Charakterystyka strat wody}

Charakterystyka strat wody w przedsiębiorstwie powinna zawierać informacje na temat objętości wody sprzedanej przez przedsiębiorstwo, objętości wody zużytej przez przedsiębiorstwo (w celach produkcji wody, płukania sieci itp.) oraz strat wody.

Straty wody dzielą się na rzeczywiste i pozorne.

Straty rzeczywiste: określane są najczęściej w przedsiębiorstwach wodociągowych na podstawie różnicy rocznego bilansu całkowitych strat oraz zużycia wody na potrzeby własne systemu. Powodowane są wyciekami z nieszczelności przewodów wodociągowych, armatury, nieszczelnych instalacji.

Straty pozorne: objętości wody, które nie stanowią faktycznych wycieków. Są to straty wynikające z niedokładności i niejednoznaczności pomiarów, czyli tzw. błędów pomiarowych wynikających ze źle dobranych urządzeń pomiarowych, błędów metrologicznych, kradzieży wody. Na wielkość strat pozornych wody (definiowanych jako niestanowiące faktycznych ubytków z nieszczelnego systemu sieciowego, ale jedynie wpływające na wartość obliczeniowego wskaźnika strat, to znaczy na wynik liczbowy bilansu ilości wody wtłoczonej do sieci i sprzedanej odbiorcom) wpływają dokładność pomiaru objętości medium dostarczonego do sieci i zużytej przez odbiorców oraz niejednoczesność odczytów przyrządów pomiarowych objętości wody w miejscu dostawy do sieci i u odbiorców.

Można przyjąć uproszczoną definicję strat wody: „objętość bezpowrotnie utraconej wody w wyniku jej nieracjonalnego zużycia z przyczyn zależnych i niezależnych od zarządzającego siecią wodociągową". Także prawidłowe jest stwierdzenie, że systematyczna eliminacja czynników zależnych i niezależnych oraz umiejętny dobór urządzeń pomiarowych prowadzą do ograniczenia strat wody (Mutikanga i in. 2013).

Do czynników zależnych należą (Piechurski i Mierzwa 2020):

- nieszczelności na złączach przewodów wodociągowych - awarie;

- przecieki wody z nieszczelnego uzbrojenia wodociągowego - awarie;

- nieszczelności na przyłączach wodociągowych - awarie;

- płukanie sieci wodociągowej;

- klasa dokładności urządzeń pomiarowych.

Czynniki częściowo niezależne to:

- kradzieże wody;

- awarie wodociągowe.

Ponadto widoczny w ostatnich latach spadek zużycia wody wywołany m.in. urynkowieniem cen wody i ścieków, a także wprowadzeniem indywidualnego opomiarowania zużycia wody spowodował, że wśród wielu czynników powodujących straty wody w systemach wodociągowych, coraz większego znaczenia nabierają kradzieże wody wynikające z zewnętrznej ingerencji w wodomierz lub instalację. 


\section{Przyczyny uszkodzeń przewodów wodociągowych}

Awarie przewodów wodociągowych mają w większości przypadków charakter losowy, a ustalenie przyczyn ich powstania jest często trudne ze względu na różnorodność czynników oddziałujących równocześnie na przewody. Błędne obliczenia hydrauliczne, nieprawidłowe wykonanie złączy czy niedbała konserwacja to tylko przykłady przyczyn późniejszych awarii elementów układów wodociągowych. Liczne badania wskazują, że najczęściej uszkodzenia sieci wodociągowych i związane z tym straty wody powstają w wyniku (Ferrari i Sawic 2015, EEA 2012, Piechurski i Mierzwa 2020, Zambrano i in. 2009):

- wad zamontowanych materiałów, co dotyczy rur, armatury, połączeń;

- nieprawidłowego wykonawstwa przewodów, np. niewłaściwe uszczelnienie połączeń kielichowych;

- nadmiernego ciśnienia w sieci;

- gwałtownych zmian ciśnienia (uderzenia hydrauliczne);

- korozyjności wód gruntowych, a także wody płynącej wewnątrz przewodów;

- przemarzania gruntu w otoczeniu przewodów wodociągowych;

- nadmiernego obciążenia gruntu nad sieciami wodociągowymi, szczególnie dynamicznego; osiadania gruntu; ruchów tektonicznych itp.;

- prądów błądzących, na obszarach miast czy zakładów posiadających trakcję elektryczną;

- wieloletniej eksploatacji i naturalnego zużycia materiałów wodociągowych.

O zaistnieniu i objętości wycieków decydują przede wszystkim:

- stan techniczny przewodów i armatury;

- średnica, wiek i materiał przewodów;

- gęstość przyłączy i przewodów wodociągowych;

- ciśnienie wody i jego wahania dobowe;

- warunki gruntowe.

Należy nadmienić, że straty wody powstają nie tylko w wyniku uszkodzenia, pęknięcia przewodów wodociągowych, wycieków na połączeniach oraz przez nieszczelności rur przesyłowych, ale również w wyniku przelewania się wody ze zbiorników magazynujących wodę lub ich nieszczelności.

\section{Wiek sieci wodociagowej}

Okres eksploatacji sieci wodociągowej oraz wiele innych czynników jak na przykład materiał, jakość wykonania złączy, warunki eksploatacji, jakość materiału itp. decydują o awaryjności sieci wodociągowej. Poniżej przedstawiono jak prezentuje się okres eksploatacji sieci wodociągowej w A (ryc. 1 i 2). Długość sieci wodociągowej wynosi 222,6 km. 
Ocena sposobów obniżenia straty wody na przykładzie PWiK w A

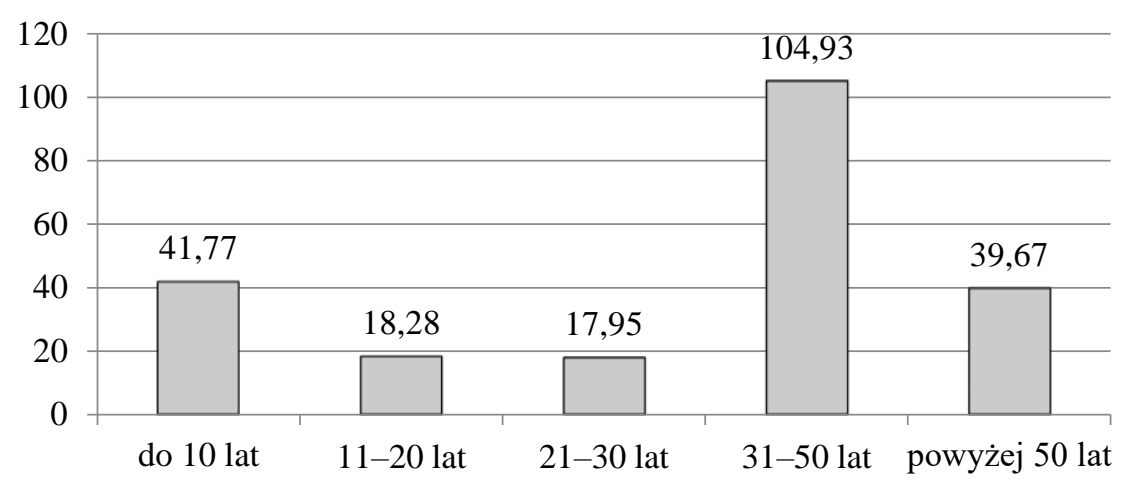

Ryc. 1. Długości eksploatowanej sieci wodociągowej w strukturze wiekowej [km] Źródło: Piechurski i Mierzwa 2020

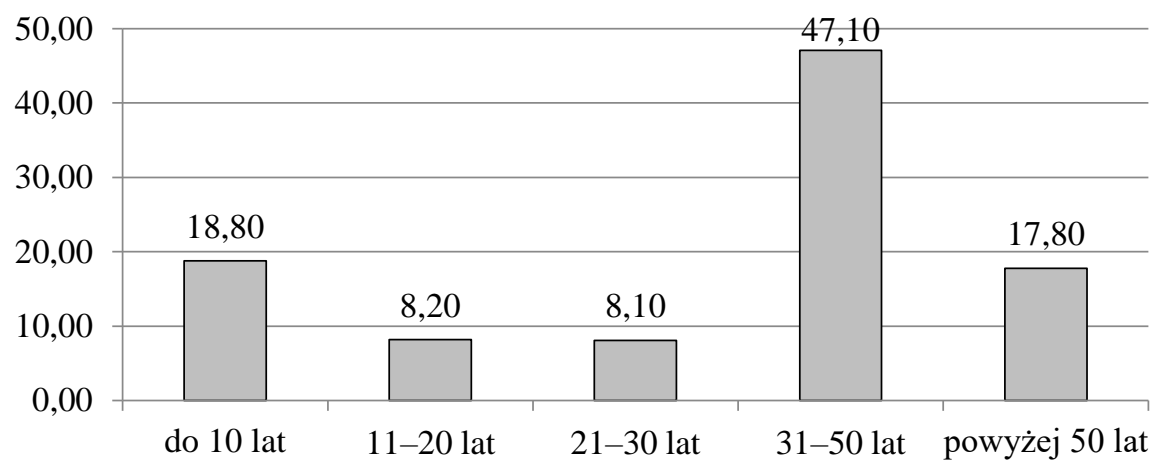

Ryc. 2. Procentowy udział sieci wodociągowej w strukturze wiekowej [\%]

Źródło: Piechurski i Mierzwa 2020

Jak widać, ponad $47 \%$ sieci jest eksploatowana od 31 . do 50 . lat oraz aż 17,8\% stanowią sieci w wieku ponad 50. lat. Podsumowując wiek sieci w A - niewątpliwie większość sieci wymaga modernizacji lub wymiany. Niestety przedsiębiorstwo nie dysponuje tak dużymi środkami finansowymi aby pozwolić sobie na znaczny zakres wymiany sieci wodociągowej. Dlatego też sieci najstarsze i najbardziej awaryjne wymieniane są co roku - w miarę możliwości finansowych przedsiębiorstwa, co pokazuje ryc. 6 .

\section{Materiat sieci wodociagowej}

Materiał jest jednym z czynników wpływających na awaryjność sieci oraz związaną z tym ilość wody traconej. Strukturę materiałową sieci w A przedstawia ryc. 3. 


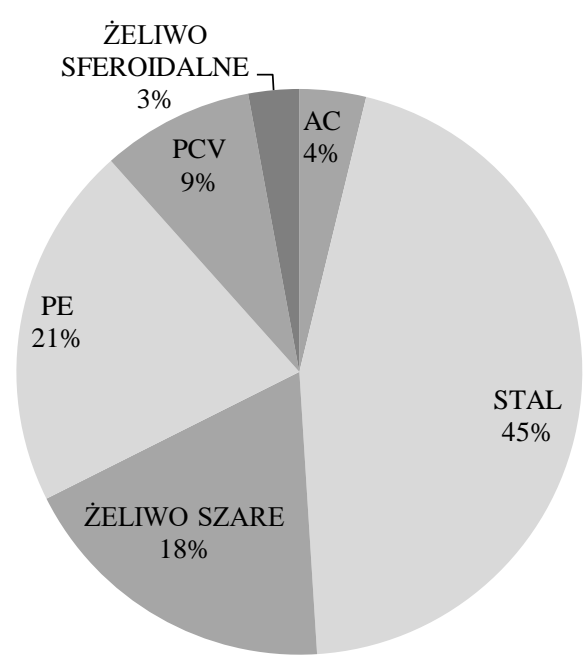

Ryc. 3. Struktura materiałowa sieci wodociągowej - stan na 31.12.2016 r.

Źródło: Piechurski i Mierzwa 2020

Analizując wykres (ryc. 3) widać, że największą część sieci wodociągowej stanowią rurociągi stalowe, których większość została wybudowana w latach 60-, 70- i 80-tych XX wieku. Sieci ze stali oraz żeliwa szarego są najbardziej awaryjnymi eksploatowanymi w A. Chcąc znacznie zmniejszyć straty w sieci wodociągowej, w pierwszej kolejności należałoby wymieniać właśnie te sieci, które generują największe straty.

Awarie na sieci wodociagowej

Rycina 4 pokazuje jak przedstawiała się liczba awarii na sieci wodociągowej na przestrzeni 6. lat od roku 2011 do 2016.

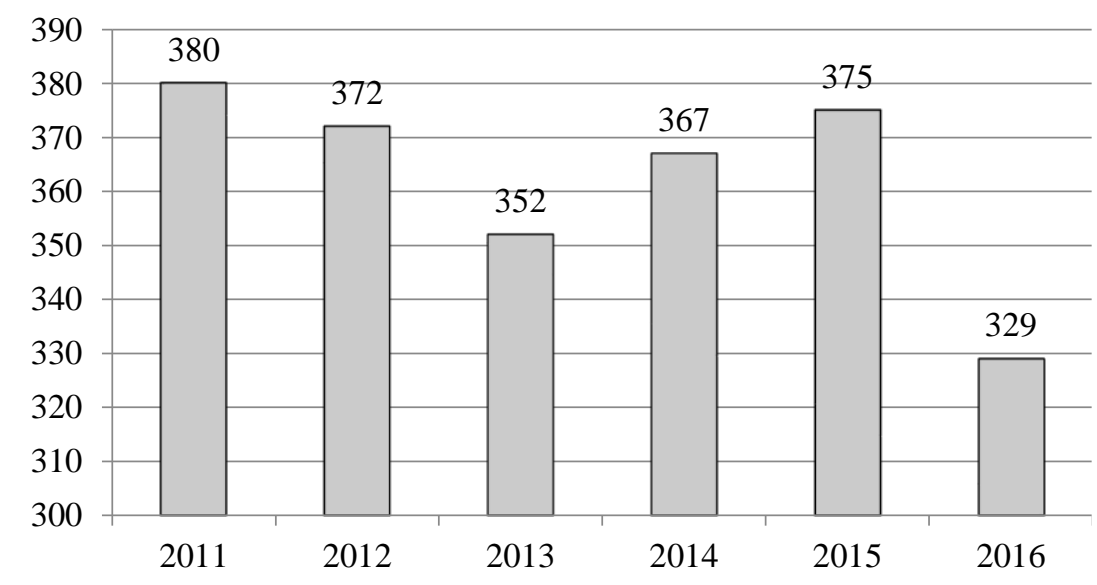

Ryc. 4. Liczba awarii na sieci wodociągowej w latach 2011-2016 [szt.]

Źródło: Piechurski i Mierzwa 2020 
Liczba awarii w badanych latach nieznacznie się różni. Największy spadek liczby awarii na sieci wodociągowej odnotowano między 2015 a 2016 rokiem, czyli o 46 awarii mniej. Oczywiście największy wpływ na liczbę tych awarii ma wiek sieci i materiał.

$\mathrm{W}$ tabeli 1 zestawiono obliczone wskaźniki awaryjności (liczba awarii $/ \mathrm{km}$ i rok) w latach 2011-2016. Widać wyraźnie, że jest on bardzo duży i na jego podstawie można ocenić stan techniczny sieci jako niezadawalający - zły.

Tab. 1. Wskaźnik awaryjności w sieci wodociągowej w latach 2011-2016 [liczba awarii/km]

\begin{tabular}{|c|c|c|c|c|c|}
\hline $\mathbf{2 0 1 1}$ & $\mathbf{2 0 1 2}$ & $\mathbf{2 0 1 3}$ & $\mathbf{2 0 1 4}$ & $\mathbf{2 0 1 5}$ & $\mathbf{2 0 1 6}$ \\
\hline 1,71 & 1,67 & 1,58 & 1,65 & 1,68 & 1,48 \\
\hline
\end{tabular}

Źródło: Piechurski i Mierzwa 2020.

\section{Liczba awarii na przylaczach wodociagowych}

Niewątpliwie bardzo ważnym czynnikiem wpływającym na poziom strat jest stan techniczny przyłączy wodociągowych. Aktualnie w A eksploatowane są 8202 przyłącza wodociągowe.

Wykrycie awarii na sieci wodociągowej najczęściej następuje bardzo szybko ponieważ jest od razu widoczne w monitoringu i szybko zgłaszane, natomiast awarie na przyłączach wodociągowych są najczęściej długotrwałe i trwają nawet do kilku lat, i generują przez ten czas często większe straty niż awarie na sieciach, które usuwane są w trybie natychmiastowym. Liczbę awarii na przyłączach wodociągowych przedstawia ryc. 5 .

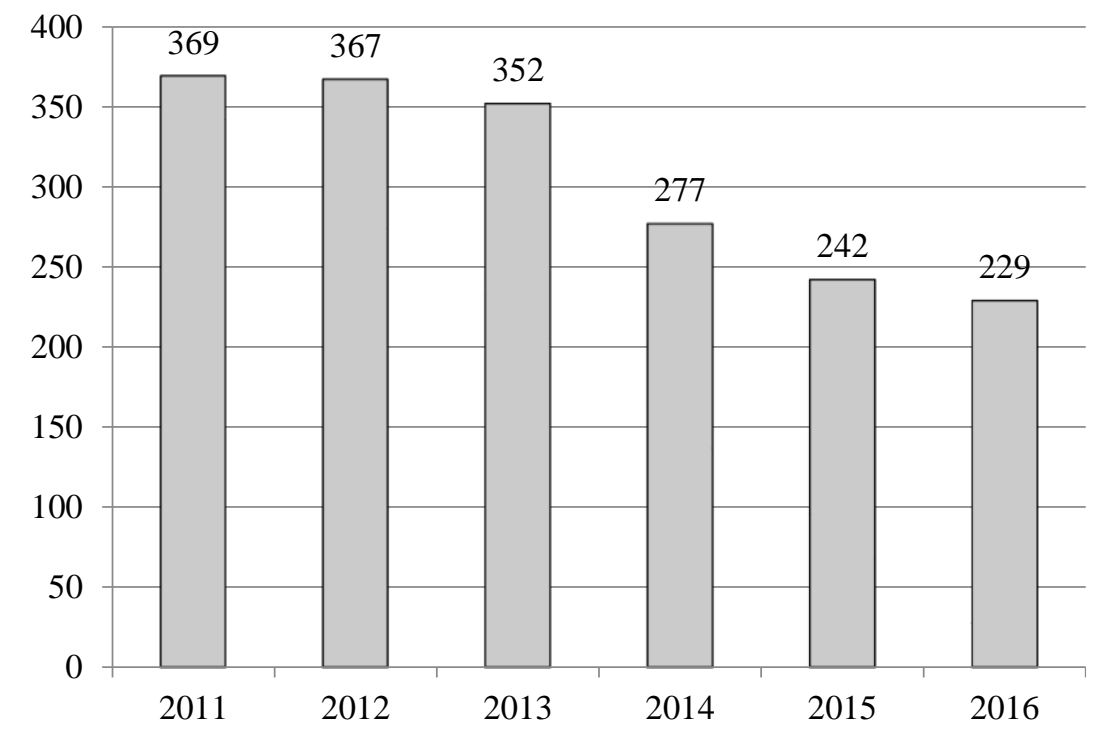

Ryc. 5. Liczba awarii na przyłączach wodociągowych w latach 2011-2016 [szt.]

Źródło: Piechurski i Mierzwa 2020 
Wykres na rycinie 5 pokazuje, że występuje tutaj tendencja spadkowa - z roku na rok awarii na przyłączach wodociągowych jest coraz mniej. Największy spadek liczby awarii na przyłączach wodociągowych odnotowano w 2014 roku - o 75 mniej niż w roku 2013. Oceniając wskaźniki awaryjności na przyłączach wodociągowych (tab. 2) można zauważyć tendencję spadkową, ale jest on dalej bardzo wysoki i wymaga prowadzenia działań naprawczych, czyli wymiany stalowych na PEHD.

Tab. 2. Wskaźnik awaryjności na przyłączach wodociągowych w latach 2011-2016 [liczba awarii/km]

\begin{tabular}{|c|c|c|c|c|c|}
\hline $\mathbf{2 0 1 1}$ & $\mathbf{2 0 1 2}$ & $\mathbf{2 0 1 3}$ & $\mathbf{2 0 1 4}$ & $\mathbf{2 0 1 5}$ & $\mathbf{2 0 1 6}$ \\
\hline 1,67 & 1,65 & 1,58 & 1,24 & 1,09 & 1,03 \\
\hline
\end{tabular}

Źródło: Piechurski i Mierzwa 2020

\section{Wymiana i budowa sieci wodociągowych}

„Odmładzanie” (wymiana, renowacja) eksploatowanych sieci wodociągowych jest jednym z głównych składników strategii przedsiębiorstwa i planowane jest w tymże przedsiębiorstwie w okresach dwuletnich. Wymiana, czy też budowa sieci wodociągowych, stanowi znaczną część budżetu firmy, dlatego też planowanie takich inwestycji jest starannie przemyślane i konsultowane na wielu szczeblach przedsiębiorstwa - tak, aby optymalnie dopasować inwestycje, a zarazem zmniejszyć poziom strat oraz związanych z tym pośrednich kosztów. Długości wymienianych sieci wodociągowych w latach 2010-2016 przedstawia ryc. 6.

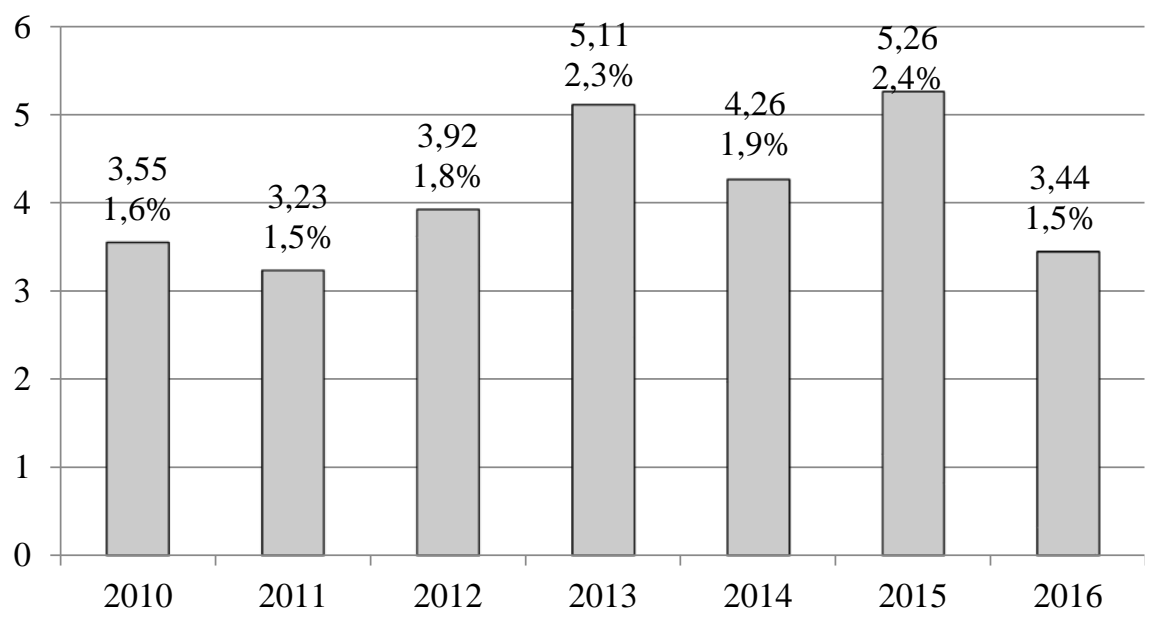

Ryc. 6. Długość wymienionych/wybudowanych sieci wodociągowych w latach 2010-2016 ([km] i procentowy udział w stosunku do całej długości sieci)

Źródło: Piechurski i Mierzwa 2020

W ostatnich 7. latach zostało wymienionych/wybudowanych prawie $30 \mathrm{~km}$ sieci, co stanowi niestety tylko około $13 \%$ całej eksploatowanej sieci. Na przestrzeni 10. lat większość nowych sieci budowanych jest z PE - 84\%, a pozostałe z żeliwa sferoidalnego - 16\% (ryc. 7). 


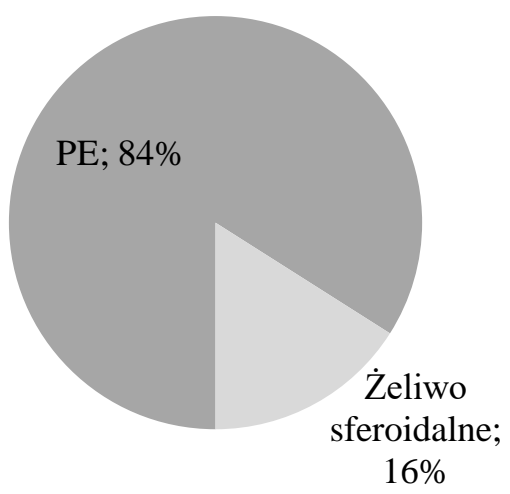

Ryc. 7. Materiał wymiany/budowy sieci wodociągowych w ostatnich 7. latach Źródło: Piechurski i Mierzwa 2020

\section{Wymiana i budowa przyłączy wodociągowych}

Przedsiębiorstwo systematycznie wymienia przyłącza wodociągowe będące w jego eksploatacji. Większość przyłączy wodociągowych jest w eksploatacji odbiorców wody i do nich należy wymiana przyłączy będących w złym stanie technicznym. Przedsiębiorstwo nie jest w stanie pozwolić sobie na wymianę tych przyłączy na własny koszt. W przypadku wymiany sieci wodociągowych $\mathrm{w}$ większości przypadków przyłącza są wymieniane na nowe, a dla budowy nowych sieci wodociągowych projektowane są również przyłącza wodociągowe wraz ze studnią wodomierzową zlokalizowaną do $2 \mathrm{~m}$ za granicą działki. Liczba oraz długość wymienianych przyłączy wodociągowych w latach 2010-2016 została pokazana na wykresie (ryc. 8).

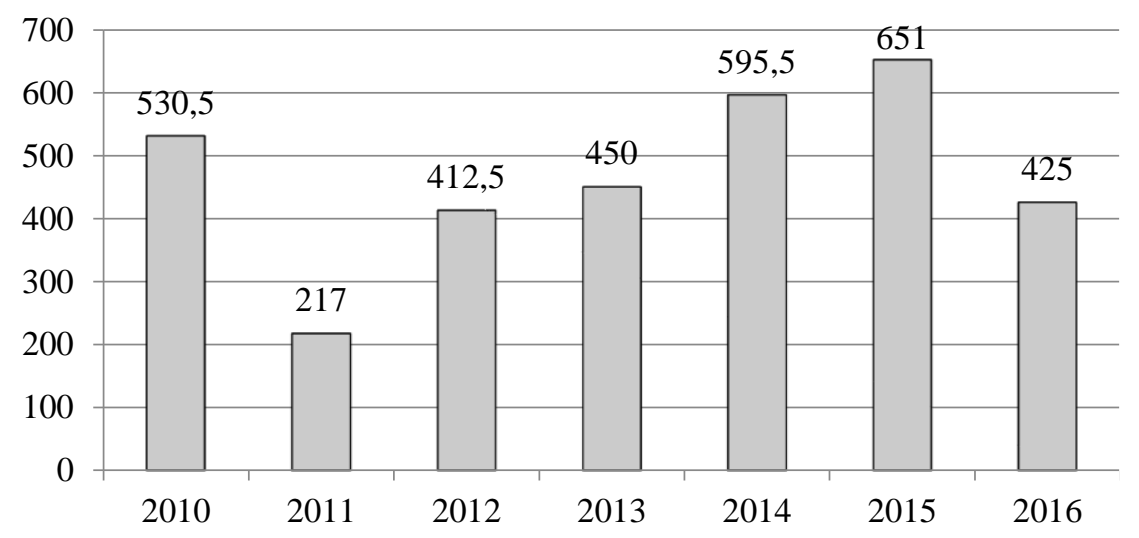

Ryc. 8. Wymiana przyłączy wodociągowych w latach 2010-2016 [m]

Źródło: Piechurski i Mierzwa 2020

Wymiana przyłączy na przestrzeni ostatnich 7. lat była bardzo zróżnicowana. W 2015 roku wymieniono najwięcej metrów bieżących przyłączy wodociągowych, a najmniej w $2011 \mathrm{r}$. 


\section{Bilans wody}

W tab. 3 i na ryc. 9. przedstawiony został bilans produkcji, sprzedaży i strat wody w latach 2012-2016.

Tab. 3. Bilans wody na przestrzeni w latach $2012-2016$

\begin{tabular}{|l|r|r|r|r|r|}
\hline Parametr (jednostka)/rok & \multicolumn{1}{c|}{$\mathbf{2 0 1 2}$} & \multicolumn{1}{|c|}{$\mathbf{2 0 1 3}$} & \multicolumn{1}{c|}{$\mathbf{2 0 1 4}$} & \multicolumn{1}{c|}{$\mathbf{2 0 1 5}$} & \multicolumn{1}{c|}{$\mathbf{2 0 1 6}$} \\
\hline Woda wtłoczona $\left(\mathrm{m}^{3}\right)$ & 4133348,0 & 3695125,0 & 3529101,0 & 3484374,0 & 3341604,0 \\
\hline Zużycie własne $\left(\mathrm{m}^{3}\right)$ & 182398,0 & 177985,0 & 191232,0 & 193383,0 & 208099,0 \\
\hline Płukanie sieci $\left(\mathrm{m}^{3}\right)$ & 206667,4 & 184756,3 & 176455,1 & 174218,7 & 167080,2 \\
\hline Sprzedaż $\left(\mathrm{m}^{3}\right)$ & 1964376,0 & 1862292,0 & 1864625,0 & 1999780,0 & 2077015,0 \\
\hline Strata $\left(\mathrm{m}^{3}\right)$ & 1779907,0 & 1470092,0 & 1296789,0 & 1116992,0 & 889409,8 \\
\hline Strata $(\%)$ & 43,0 & 39,8 & 36,7 & 32,0 & 26,6 \\
\hline
\end{tabular}

Źródło: Piechurski i Mierzwa 2020.

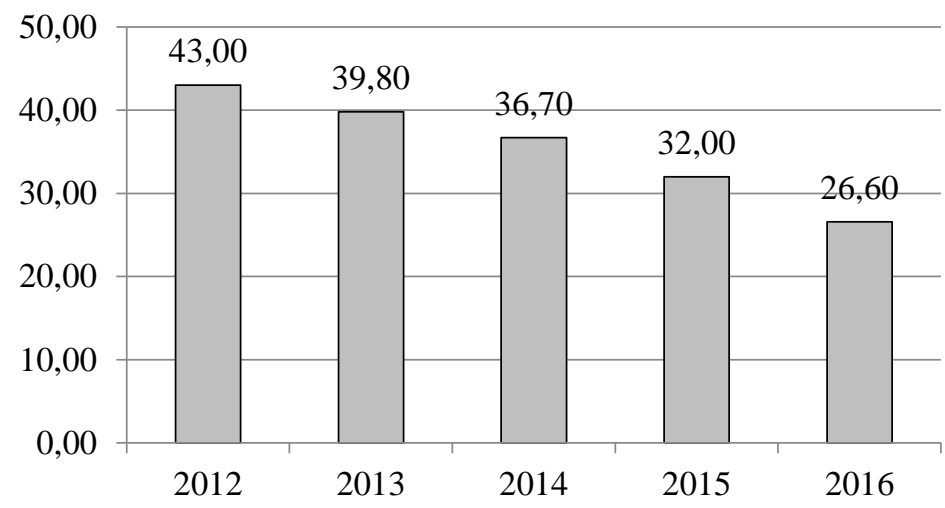

Ryc. 9. Poziom strat w latach 2012-2016 [\%]

Źródło: Piechurski i Mierzwa 2020

Analiza danych z tab. 3 i ryc. 9 pozwala stwierdzić, że z roku na rok straty systematycznie maleją. Nie jest to bardzo duży spadek strat, lecz stabilne coroczne pomniejszanie ich o kilka procent. Celem przedsiębiorstwa jest osiągniecie poziomu $8-12 \%$, lecz wymaga to niestety czasu oraz dużych nakładów finansowych związanych z budową, czy też renowacją sieci i przyłączy oraz innymi czynnikami wpływającymi na poziom strat wody.

\section{Strefy pomiaru}

Miasto A w roku 2016 podzielone było na 11 stref zasilania w wodę oraz 29 studni pomiarowych pozwalających na monitorowanie obszarów sieci wodociągowej w celu jak najszybszego wykrywania nieszczelności w przewodach wodociągowych.

\section{Redukcja ciśnienia w sieci}

$\mathrm{Na}$ ujęciach wody wtłaczających medium bezpośrednio do sieci wodociągowej zamontowane są falowniki, które regulują natężenie przepływu wtłaczanej wody z zadanym ciśnieniem. 
Ponadto na sieci zabudowanych jest siedem reduktorów ciśnienia oraz jeden zawór pierwszeństwa. Przepływ wody w sieci, ciśnienie i wiele innych czynników podlegają ciągłej analizie przez pracowników, a następnie wprowadzane są odpowiednie działania mające na celu optymalizację ciśnienia wody oraz zapobieganie zwiększania strat spowodowanych wyciekami. Jak wiadomo wyższe ciśnienie wody w sieci powoduje wielokrotny wzrost wypływu z przykładowego wycieku jak również powstawanie nowych awarii.

\section{Monitoring sieci wraz z przykladami i analiza}

PWiK w A wykorzystuje monitoring dla stref urządzenia do pomiaru przepływu i ciśnienia. Dane te przesyłane są za pomocą telefonii komórkowej GSM. W studniach pomiarowych zabudowywane są urządzenia Cello - bezprzewodowe rejestratory danych. Urządzenia współpracują z oprogramowaniem PMAC firmy Technolog. Możliwość odczytu danych występuje co 8 godzin, a następnie dane te można analizować w dokładniejszych odstępach czasu (minutowych - kilkunastominutowych, w zależności od ustawienia rejestratora).

Dla ujęć wody wykorzystywany jest monitoring wewnętrzny, gdzie przekaz bezpośredni pomiaru ciśnienia i przepływu przekazywany jest przez Internet oraz sieć GSM. Monitoring sieci jest niezbędny do wykrywania wycieków w sieci wodociągowej. Na rycinie 10 widać kilka kilkunastominutowych pobrań wody $\mathrm{z}$ hydrantu lub nieopomiarowanych poborów wody $\mathrm{Z}$ wodociągu. $\mathrm{Z}$ uwagi na krótki czas poboru wody, niezwykle trudnym jest wykrycie takich poborów. Woda ta najczęściej pobierana jest do napełniania zbiorników wodnych, studni, basenów itp.

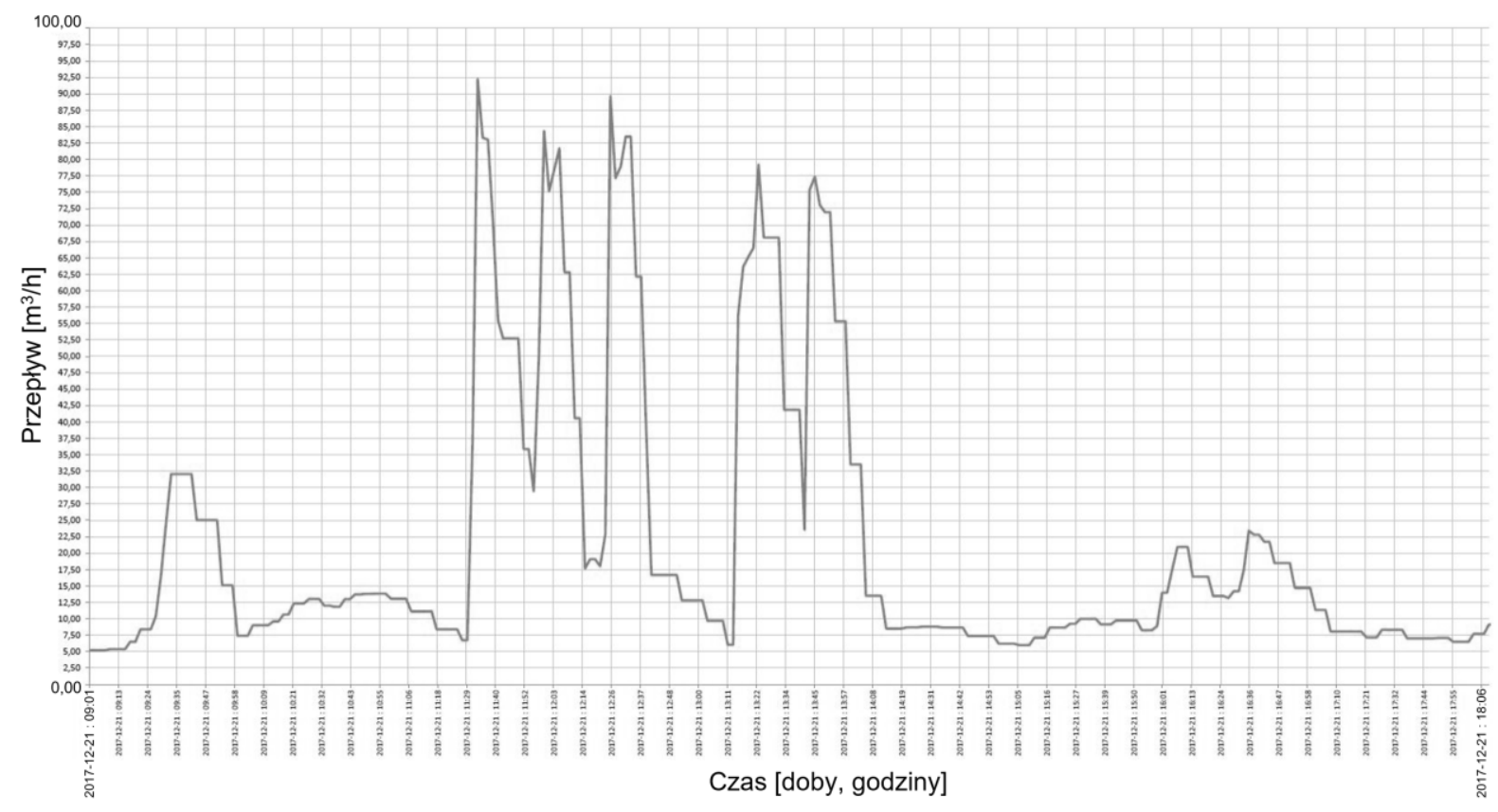

Ryc. 10. Nieopomiarowany pobór wody $\left[\mathrm{m}^{3} / \mathrm{h}\right] \mathrm{z}$ hydrantu lub wodociągu (09:01-18:06, 21 XII $2021 \mathrm{r}$.)

Źródło: Piechurski i Mierzwa 2020 
Na ryc. 11 widać, że przed wystąpieniem dwóch awarii przepływ nocny był na poziomie $46 \mathrm{~m}^{3} / \mathrm{h}$, a po wystąpieniu awarii zwiększył się do $94 \mathrm{~m}^{3} / \mathrm{h}$. Od razu zareagowano i usunięto jedną awarię, co spowodowało spadek przepływu nocnego do $68 \mathrm{~m}^{3} / \mathrm{h}$, a następnie w kolejnym dniu usunięto kolejną awarię, co unormowało przepływ nocny w tym obszarze do poziomu średnio $46 \mathrm{~m}^{3} / \mathrm{h}$.

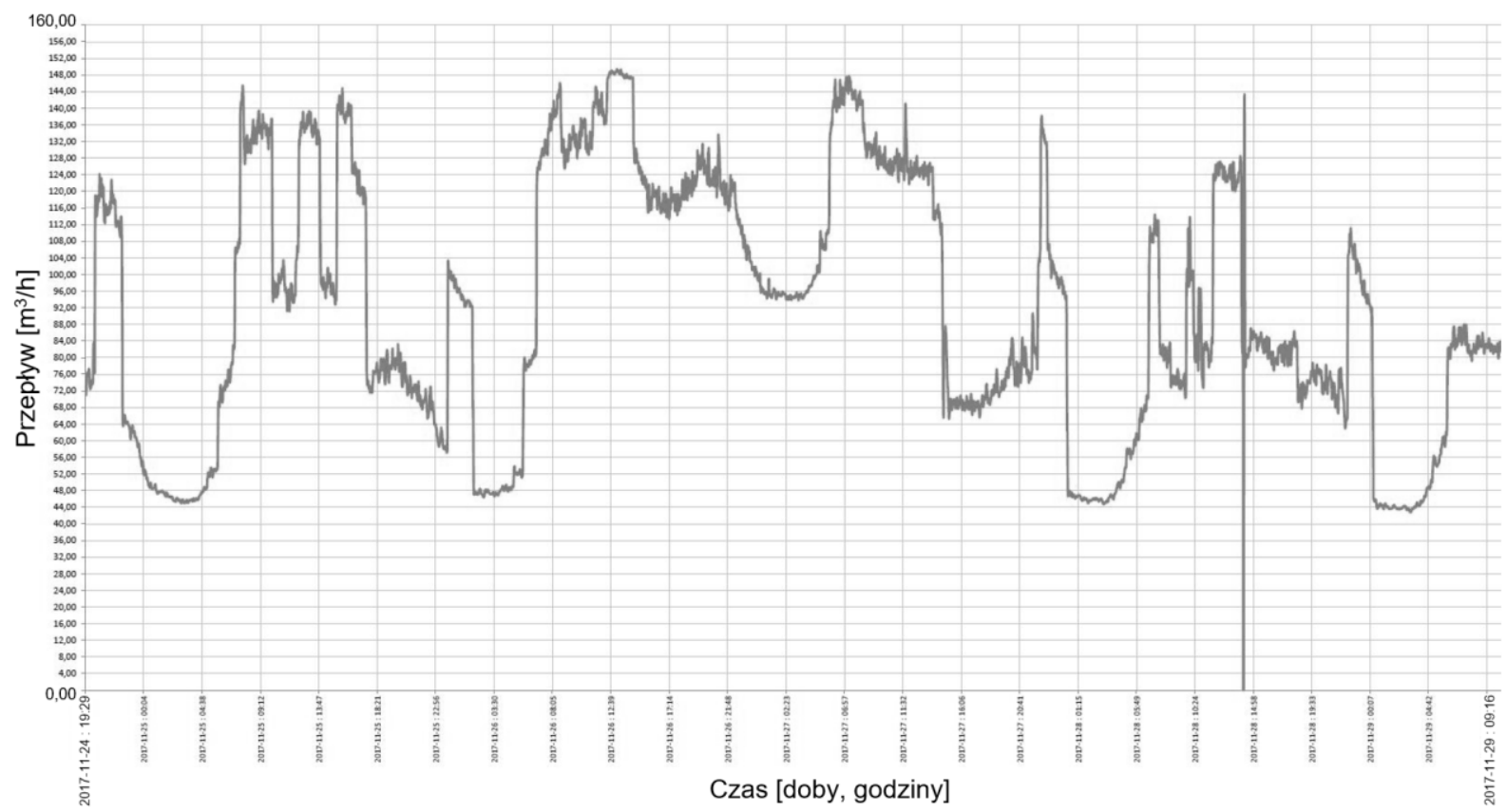

Ryc. 11. Przepływ wody $\left[\mathrm{m}^{3} / \mathrm{h}\right]$ przed i po usunięciu 2. awarii (19:29, 24 XI-09:16, 29 XI $2017 \mathrm{r}$.)

Źródło: Piechurski i Mierzwa 2020

\section{Minimalny nocny przeplyw}

Bardzo ważnym elementem monitoringu jest MNP - minimalny nocny przepływ. Jest to powtarzające się codziennie minimalne natężenie przepływu w okresie nocnym $\mathrm{w}$ godzinach od 01:00 do 05:00. Aby prawidłowo analizować MNP należy znać charakter odbiorców w danej strefie. Trzeba pamiętać, że w nocy też zdarzają się rozbiory (przemysł, napełnianie zbiorników itp.). Dzięki codziennej analizie przepływów nocnych można łatwo ustalić zaistnienie nieszczelności na sieci czy też nocne kradzieże wody. Przykład przepływu w trakcie i po awarii pokazany jest na ryc. 12 .

Na rycinie 12 widać, że przepływ nocny w analizowanej strefie wynosił przed 16 . listopada około $32 \mathrm{~m}^{3} / \mathrm{h}$, a po usunięciu awarii przepływ nocny spadł do około $9 \mathrm{~m}^{3} / \mathrm{h}$. Najwyższe widoczne na rysunku skoki to najczęściej płukania sieci lub kradzieże z hydrantów. 


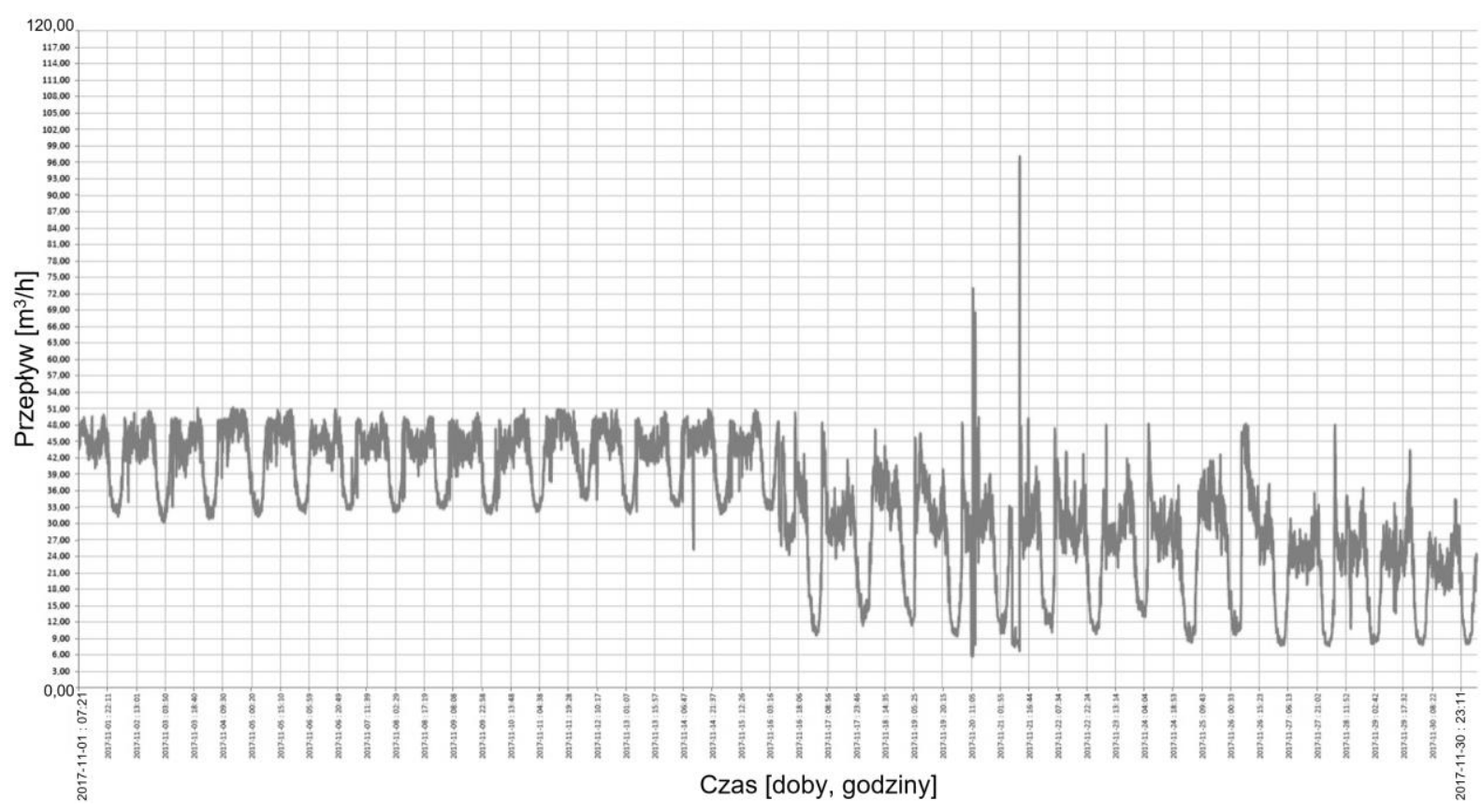

Ryc. 12. Przepływ wody $\left[\mathrm{m}^{3} / \mathrm{h}\right]$ w okresie $07: 21,01 \mathrm{XI}-23: 11,30$ XI $2017 \mathrm{r}$.

Źródło: Piechurski i Mierzwa 2020

\section{Urzadzenia do lokalizacji wycieków i armatury}

PWiK w A dysponuje następującymi urządzeniami wspomagającymi wykrywanie awarii oraz lokalizacji rur i kabli:

- Loggery akustyczne - permalogi (pomiar szumów) - 15 sztuk;

- Geofon;

- Minigeofon;

- Korelator cyfrowy;

- sprzęt do lokalizacji instalacji podziemnych i odszukiwania armatury: CS-CAT XD z Generatorem Sygnału oraz MagnaTrak.

\section{Zmniejszanie strat wody}

Poniżej przedstawiono działania stosowane w przedsiębiorstwie mające na celu zmniejszanie strat wody:

- monitoring pracy sieci wodociągowej;

- redukcja ciśnienia do poziomu minimalnego - falowniki na ujęciach;

- szybka reakcja na ujawnione wycieki - szybkie naprawy uszkodzonej sieci;

- aktywna kontrola wycieków;

- coroczna wymiana najbardziej awaryjnych sieci i przyłączy wodociągowych;

- budowa/wymiana sieci wodociągowych wraz z przyłączami;

- stosowanie najwyższej klasy urządzeń pomiarowych;

- kontrola odbiorców o bardzo małym zużyciu wody (prawdopodobieństwo kradzieży); 
- odpowiednie wykonawstwo (głębokość, podsypka, obsypka, utwardzanie gruntu, materiały, połączenia, dokładność przy wykonawstwie);

- zabudowa reduktorów ciśnienia i zaworów pierwszeństwa.

\section{Propozycje ograniczania strat wody na kolejne lata}

Na kolejne lata proponuje się kontynuację działań jak wyżej i również dodatkowo:

- zawężanie stref poprzez budowę dodatkowych studni pomiarowych;

- montaż większej liczby reduktorów ciśnienia wody celem ustabilizowania ciśnienia w sieci;

- montaż urządzeń odpowietrzających sieć celem zminimalizowania skutków uderzeń hydraulicznych.

\section{Podsumowanie}

Wycieki w sieciach i przyłączach wodociągowych są nieuniknionym zjawiskiem występującym w każdym systemie zaopatrzenia $\mathrm{w}$ wodę. Jest to nieprzewidywalne zjawisko, którego czasu ani miejsca nie jest $\mathrm{w}$ stanie przewidzieć żaden człowiek ani przedsiębiorstwo wodociągowe.

Przyczyny awarii mogą być bardzo różne i często jednoznaczne ustalenie przyczyny jest po prostu niemożliwe. W wielu przypadkach przyczyny te nakładają się na siebie.

Wysokie wskaźnik awaryjności w sieci powyżej 1,5 awarii/km rok świadczą o złym stanie technicznym i dużych problemach związanych z jej eksploatacją.

Efektem uszkodzeń sieci wodociągowych są straty, które stanowią często wysoki procent wody wtłaczanej do sieci.

Działania związane z budową systemu monitoringu mające na celu obniżanie poziomu strat wody są kosztowne, lecz niezbędne.

Wycieki wody oraz kradzieże wpływają niekorzystnie na kondycje finansową zakładu oraz stwarzają możliwość zanieczyszczenia wody oraz utratę ciągłości dostaw.

W związku z powyższym podstawowym działaniem każdego przedsiębiorstwa wodociągowego winno być ograniczenie strat wody.

\section{Wnioski}

1. $Z$ przedstawionych wyników analizy widać, że działania polegające na budowie systemu monitoringu w PWiK w A przynoszą efekty.

2. Wskaźniki awaryjności są podobne w analizowanym okresie, a straty zmniejszane są corocznie o kilka procent.

3. Celem przedsiębiorstwa jest osiągnięcie strat na poziomie $8-12 \%$, co niestety wymaga czasu oraz bardzo dużych nakładów finansowych, a biorąc pod uwagę wiek sieci - zadanie to będzie bardzo trudne do osiągnięcia. 


\section{Bibliografia}

Clarke M., Boden P., McDonald A., 2012, Debtor: debt evaluation, benchmarking and tracking - a water debt management tool to address UK water debt, Water Environ J. 2012, 26(3): 292-300.

European Environment Agency, 2012, Towards efficient use of water resources in Europe, EEA Report No 1/2012, https://www.eea.europa.eu/publications/towards-efficientuse-of-water (dostęp: 21.08.2021).

Ferrari G., Savic D., 2015, Economic performance of DMAs in water distribution systems, Procedia Engineering, 2015, 119: 189-195.

Mutikanga H., Sharma S., Vairavamoorthy K., 2013, Methods and tools for managing losses in water distribution systems, Journal of Water Resources Planning and Management, 2013, 139(2): 166-174.

Piechurski F., Mierzwa T., 2020, Ocena działań zmniejszajacych do obniżenie awaryjności $i$ strat wody $w$ sieci wodociagowej na przykladzie miasta $Z$ w latach 2012-2017, INSTAL, 11(419)/2020: 41-46.

Zambrano J.A., Gil-Martinez M., Garcia-Sanz M., Irizar I., 2009, Benchmarking of control strategies for ATAD technology: a first approach to the automatic control of sludge treatment systems, Water Science \& Technology 2009, 60(2): 409-417.

Zygmanowski F., 1957, Walka ze stratami wody w sieciach wodociagowych, Warszawa. 